\title{
Assessment of Heavy Metals Level of Soils Around Sacks and Packaging Company, Akwanga Nasarawa State, Nigeria
}

Emmanuel Amuntse Yerima*, Raymond Bwano Donatus, Ifeoma Juliet Opara, Godwin Ogbaji Egah and Joseph Dennis Ani

Department of Chemical Sciences, Federal University Wukari, PMB 1020, Taraba State, Nigeria

${ }^{*}$ Corresponding author: Yerima EA, Department of Chemical Sciences, Federal University Wukari, PMB 1020, Taraba State, Nigeria, Tel: +234800000000; E-mail: yerimaemmanuel@yahoo.com

Received date: November 12, 2018; Accepted date: December 05, 2018; Published date: December 10, 2018

Copyright: @ Yerima EA, et al. 2018 This is an open-access article distributed under the terms of the Creative Commons Attribution License, which permits unrestricted use, distribution, and reproduction in any medium, provided the original author and source are credited.

\begin{abstract}
Increasing industrial activity around the world has left behind large number of contaminants such as heavy metals which can easily get into food chain and bio-cumulate in tissues of living organism with detrimental effect. This study was carried out to assess the impact of activities in a sack production and packaging company on the level of heavy metal on soils around the industrial layout. The results obtained from the soil analysis reveals that the $\mathrm{pH}$, organic carbon and organic matter content of the test and control soils were (8.40 \pm 0.20 and $8.51 \pm 0.01),(1.76 \pm 0.030$ and $0.92 \pm 0.02 \%)$ and $(3.03 \pm 0.33$ and $0.55 \pm 0.05 \%)$ respectively. While the available phosphorus content, nitrogen and effective cation exchange capacity of the test and control soil samples were (3.62 \pm 0.02 and $4.11 \pm 0.10 \%)$, $(0.251 \pm 0.01$ and $0.078 \pm 0.001 \%)$ and $(65.59 \pm 0.05$ and $14.78 \pm 0.01 \mathrm{Meq} / 100 \mathrm{~g})$ respectively which were within the limits of normal agronomical soil. The mean \pm standard deviation of heavy metal concentrations in the test and control soil were Fe $(4625.32 \pm 0.252 \mathrm{mg} / \mathrm{kg}$ and $3676.44 \pm 0.57 \mathrm{mg} / \mathrm{kg}), \mathrm{Ni}(48.20 \pm 0.128 \mathrm{mg} / \mathrm{kg}$ and $27.50 \pm 0.11$ $\mathrm{mg} / \mathrm{kg})$ Co $(36.85 \pm 0.046 \mathrm{mg} / \mathrm{kg}$ and $37.05 \pm 0.044 \mathrm{mg} / \mathrm{kg})$ and $\mathrm{Pb}(321.45 \pm 0.038 \mathrm{mg} / \mathrm{kg}$ and $174.23 \pm 0.088$ $\mathrm{mg} / \mathrm{kg}$ ) respectively where the mean concentrations of the heavy metals in the soil are in the order: $\mathrm{Fe}>\mathrm{Pb}>\mathrm{Ni}>\mathrm{Co}$ while $\mathrm{Cd}$ and $\mathrm{Cr}$ were below detection limit. The impact of the industrial activities determines using indices such as Geo-accumulation index and contamination factor indicates high contamination of the soil with lead, a non-essential element responsible for lead poisoning. Also, the statistical analysis showed a general significant difference between the mean content of heavy metal between the soil around the industry and the soil around the control site suggesting that metal enrichment is likely due to anthropogenic activity since the metal level in the test soil were generally higher with the exception of cobalt.
\end{abstract}

Keywords: Soil; Heavy metals; Geo accumulation index; Contamination factor

\section{Introduction}

Older packaging methods like multi-ply paper sacks, cotton bags, jute bags, had been used to cart away agricultural produce and industrial products. Due to the inadequacy of these packaging methods to withstand various atmospheric conditions, leading produce spoilage and financial losses and frustration to farmers and producers has led to the production of synthetic sacks from polypropylene. Polypropylene sacks are suitable for almost all the products that have used paper sacks, cotton bags, jute bags for packaging. These sacks are better suited for storage due to their strength, durability and ability to withstand water and pests [1].

The use of synthetic sacks is steadily increasing in the agricultural and manufacturing sector, with increasing agricultural yields alongside other industrial products with polypropylene being the major raw material which is said to affect the endocrine system, cause genetic mutations and tumors. Also, unlike the tradition sack, synthetic sack is not easily degradable by nature and steps involve during production as well as the raw materials employed may impart the environment and hence this study seek to evaluate the impact of activities on Nasara Packaging company on some heavy metal concentration which is now a global phenomenon. As a result of the increasing concern on the potential effects of the metallic contaminants on human and environment health, the research on fundamental, applied and health aspects of trace metals in the environment is also increasing [2]. The industrialization of the world has led to a dramatic increase in the overall environmental load of heavy metal. Industrial processes that release a variety of heavy metals into the environment may include mining, smelting, refining and almost all industrial processes that produce waste discharges are potential sources of heavy metals to the environment [3]. Heavy metals can easily get into food chain and biocumulate in tissues of living organism resulting in detrimental effect especially when present in elevated concentration hence the need to employ technologies that can remove contaminants in the environment [4]. Nevertheless, the aim of this work is to assess the impact of activities in the sack production and packaging industry on the concentration of heavy metals on surrounding soils.

\section{Study area}

Nasara sacks and packaging company, Akwanga with the geographical coordinates 55'20.964" N (latitude) and 21'25.74612" E (longitude), is situated along Akwanga - Abuja road in Akwanga about $58.4 \mathrm{~km}$ from Lafia the capital of Nasarawa State located in the NorthCentral geopolitical zone of Nigeria. The industry was established in the year 2010 .

\section{Sample collection}

The stratified sampling technique was applied for soil sample collection with little modification [5]. Under this sampling technique, the sampling site was broken into four (4) stratums (small areas) north, 
south, east and west with respect to Nasara sacks and packaging company. Each strata were further subdivided into four quadrants of equal size before five (5) samples were taken randomly by grab method within the depth of $0-15 \mathrm{~cm}$ in the individual quadrant (smaller area) making a total of twenty (20) samples per strata (small area) and a total of eighty (80) samples from the four stratums situated at the north, south, east and west of the industry were pooled together to form the composite sample labeled to enable detailed representation of variability within the study area. The control soil sample for the industry was collected in a farmland within $1.4 \mathrm{~km}$ radius from the industry from site remote to possible sources of contamination associated with the industry.

\section{Sample preparation}

The composite and the control sample were each sorted, pebbles and coarse materials removed and then air-dried at room temperature over three days with occasional breaking of aggregated materials with wooden roller; followed by sieving through a nonmetallic sieve with mesh hole of $2 \mathrm{~mm}$ diameter to remove stones, plant and animal's debris. The air dried and sieved soil was employed as soil sample for extraction and analysis.

\section{Determination of soil physiochemical parameters}

The $\mathrm{pH}$ was determined by homogenizing of the sample in $10 \mathrm{c}$ distilled water and stirred gently to enhance $\mathrm{H}^{+}$(Hydrogen ions) release from soil, the mixtures was then be allowed to stand for $30 \mathrm{~min}$. $\mathrm{pH}$ meter (JENWAY 2000) was used to read the $\mathrm{pH}$ value after calibration with buffer solutions of $\mathrm{pH}$ values $5.5,7.0$ and 8.0 respectively [6].

Soil organic carbon was determined by means of wet dichromate oxidation by the addition of $50 \mathrm{~mL}$ potassium dichromate $(0.5 \mathrm{M} \mathrm{K})$ and $2.5 \mathrm{~mL}$ concentrated sulphuric acid in 5\% FeS. Considering that the average content of carbon in soil organic matter is equal to $58 \%$ the conversion factor 1.724 was used to calculate the percentage of organic matter from the content of organic carbon $[7,8]$. Nitrogen in the soil was estimated using distillation and titrimetric method describe by Kjeldahl while the phosphorus content using molybdate reagent on the spectrophotometer at a wavelength of $660 \mathrm{~nm}[9,10]$.

Cation exchange capacity was determined by weighing $5.0 \mathrm{~g}$ of the dried soil was extracted with $25 \mathrm{~mL}$ of $1 \mathrm{M}$ NHAc solution four consecutive times. The leachate was used for atomic absorption spectrophotometric determination of $\mathrm{Ca}$ and $\mathrm{Mg}$ while flame photometer was used for the determination of $\mathrm{K}$ and $\mathrm{Na}[11,12]$. While the textural property of the soil was determined using the Hydrometer method [10].

Determination of Heavy Metals: The concentration of the heavy metal was determined using Atomic Absorption Spectrophotometer equipped with Zeeman's background correction. Prior to sample analysis, the flame condition was optimized for maximum absorbency and linear response while aspirating known standards.

\section{Impact assessment}

The index of geo accumulation $\left(\mathrm{I}_{\text {geo }}\right)$ actually enables the assessment of contamination by comparing the current status and pre-industrial concentrations originally bottom sediments $[13,14]$; it has also been applied in the assessment of soil contamination. The method assesses the degree of metal pollution in terms of seven enrichment classes based on the increasing numerical values of the index (Table 1). The index of geo accumulation was calculated using the Equation (1).

$$
\mathrm{I}_{\text {geo }}=\mathrm{I}_{\mathrm{o}}[\mathrm{Cn} / 1.5 \mathrm{Bn}]
$$

where, $\mathrm{Cn}$ is the measured concentration of the element in soil or sediment and $\mathrm{Bn}$ is the geochemical background value. The constant value, 1.5 , is back-ground matrix correction factor due to the lithological variations. Table 1: presents a descriptive classification for the $I_{\text {geo }}$ values [15].

\begin{tabular}{|l|l|l|}
\hline$I_{\text {geo }}$ & $I_{\text {geo }}$ class & Description of soil quality \\
\hline 0 & 0 & Uncontaminated \\
\hline $0-1$ & 1 & Uncontaminated to moderately contaminated \\
\hline $1-2$ & 2 & Moderately contaminated \\
\hline $2-3$ & 3 & Moderately to strongly contaminated \\
\hline $3-4$ & 4 & Strongly contaminated \\
\hline $4-5$ & 5 & Strongly to extremely strongly contaminated \\
\hline $5-6$ & 6 & Extremely contaminated \\
\hline
\end{tabular}

Table 1: Classification of geo-accumulation index.

\section{Contamination factor}

The assessment of soil contamination was also carried out using the contamination factor (CF) which is a single element index as well as the degree of contamination $\mathrm{Cd}$ which is the sum of contamination factors (CF) for all elements examined in the environment; the contamination factor was calculated using Equation (2).

$$
\mathrm{C}_{\mathrm{F}} \equiv[\mathrm{M}] /[\mathrm{M}]_{\mathrm{b}}
$$

Where $[\mathrm{M}]=$ Concentration of heavy metal in the studied area; $[\mathrm{M}]_{\mathrm{b}}=$ Background concentration levels of metals in soil. Background value of the metal is equal to the world surface rock average given by Barbalace [16]. The $C_{F}$ values between 0.5 and 1.5 indicates that the metals are entirely from the coastal materials whereas $\mathrm{C}_{\mathrm{F}}$ values greater than 1.5 indicates that the sources are most likely to be anthropogenic activities [17]. The different levels of degree of contamination include: low contamination for $\mathrm{CF}$ value $<1$; moderate contamination for $\mathrm{CF} \geq$ 1 to $<3$; considerable contamination for CF value $\geq 3$ to $<6$ and very high contamination for CF value $\geq 6$ as describe by Rahman et al. [18].

\section{Results and Discussion}

As presented in Table 2, the $\mathrm{pH}$, organic carbon and organic matter content of the test and control soils were $(8.40 \pm 0.20$ and $8.51 \pm 0.01)$, $(1.76 \pm 0.030$ and $0.92 \pm 0.02 \%)$ and $(3.03 \pm 0.33$ and $0.55 \pm 0.05 \%)$ respectively. With the exception of $\mathrm{pH}$, there is generally a significant difference between the test and control soil at 95\% confidence limit suggesting that activities around the industry may be responsible for the variation. The $\mathrm{pH}$ values were moderately alkaline and are generally within the acceptable status of agronomical soil. The organic carbon content of the test soil was about twice the content of the control soil while the organic matter content was more than five times the content in the control sample suggesting enrichment in carbon content due to the industrial activity on the soil. Organic matter consists of plant and animal residues at various stages of decomposition, cells and tissues of soil organisms as well as substances 
Citation: Yerima EA, Donatus RB, Opara IJ, Egah GO and Ani JD (2018) Assessment of Heavy Metals Level of Soils Around Sacks and Packaging Company, Akwanga Nasarawa State, Nigeria. J Environ Anal Chem 5: 251. doi:10.4172/2380-2391.1000251

Page 3 of 5

synthesized by soil organisms which help in improving the soil structure, enhanced cation exchange capacity and minimize erosion [14].

\begin{tabular}{|c|c|c|c|c|}
\hline S/No & Parameter & Test soil & Control soil & USDA standard \\
\hline 1 & $\mathrm{pH}$ & $8.4 \pm 0.20$ & $8.51 \pm 0.01$ & 6.1-8.5 \\
\hline 2 & Organic carbon (\%) & $1.76 \pm 0.03$ & $0.92 \pm 0.02$ & - \\
\hline 3 & Organic matter $(\%)$ & $3.03 \pm 0.33$ & $0.55 \pm 0.05$ & $0.4-1.5$ \\
\hline 4 & Nitrogen (\%) & $0.251 \pm 0.01$ & $0.078 \pm 0.001$ & $0.1-0.2$ \\
\hline 5 & Avail $\mathrm{P}(\mathrm{mg} / \mathrm{kg})$ & $3.62 \pm 0.02$ & $4.11 \pm 0.10$ & $1.0-10$ \\
\hline 6 & $\mathrm{~K}(\mathrm{Meq} / 10)$ & 1.02 & 0.20 & $0.2-1.0$ \\
\hline 7 & $\mathrm{Na}(\mathrm{Meq} / 100 \mathrm{~g})$ & 1.04 & 2.26 & $0.1-2$ \\
\hline 8 & $\mathrm{Ca}(\mathrm{Meq} / 100 \mathrm{~g})$ & 47.20 & 9.40 & $2.0-20$ \\
\hline 9 & $\mathrm{Mg}(\mathrm{Meq} / 100 \mathrm{~g})$ & 16.33 & 2.92 & $0.3-8.0$ \\
\hline 10 & $\begin{array}{ll}\mathrm{AE} & \left(\mathrm{H}^{++} \mathrm{A}^{+}\right) \\
(\mathrm{Meq} / 10) & \end{array}$ & 0.05 & 0.05 & $0.05-2.5$ \\
\hline 11 & $\operatorname{ECEC}(\mathrm{Meq} / 100 \mathrm{~g})$ & $65.59 \pm 0.05$ & $13.78 \pm 0.01$ & - \\
\hline 12 & Sand (\%) & 46 & 53 & - \\
\hline 13 & Silt (\%) & 49 & 40 & - \\
\hline 14 & Clay (\%) & 5 & 7 & - \\
\hline 15 & $\begin{array}{l}\text { Textural class base } \\
\text { on USDA standard }\end{array}$ & $\begin{array}{l}\text { Sandy } \\
\text { Loam }\end{array}$ & Sandy Loam & - \\
\hline
\end{tabular}

Table 2: Physicochemical parameters of soil samples around sack and packaging company.
The available phosphorus content, nitrogen and effective cation exchange capacity of the test and control soil samples were $(3.62 \pm 0.02$ and $4.11 \pm 0.10 \%),(0.251 \pm 0.01$ and $0.078 \pm 0.001 \%)$ and $(65.59 \pm 0.05$ and $14.78 \pm 0.01 \mathrm{Meq} / 100 \mathrm{~g}$ ) respectively as shown in Table 2, where the available phosphorus were approximately same between the test soil and the control soil; the nitrogen content of the test soil is more than 3 fold the content in the control soil while the effective cation exchange capacity of the test soil is more than 3 times the capacity of the control soil which is traceable to the to the elevated organic matter content in the test soil compare to the control soil [19]. Cation exchange capacity (CEC) of a soil is a measure of the quantity of negatively charged sites on soil surfaces that can retain positively charged ions especially when the soil is rich in clay and organic matter at $\mathrm{pH}$ near neutral [12]. The available phosphorus and nitrogen were generally within the limits of normal agronomical soil stipulated by USDA except the nitrogen content that is slightly higher.

\section{Determination of iron concentration}

The mean concentrations of iron in the test and control soil were $4625.32 \pm 0.252$ and $3676.44 \pm 0.57 \mathrm{mg} / \mathrm{kg}$ respectively as presented in Table 3 and Figure 1, there is a significant difference between the iron content of the test and control soil at $95 \%$ confidence limit which may be traceable to industrial activities. The mean concentrations of iron recorded are generally far below the average crustal value (background concentration) $41000 \mathrm{mg} / \mathrm{kg}$ of Iron reported by Barbalace [16]. Likewise, the $\mathrm{I}_{\mathrm{geo}}$ and $\mathrm{C}_{\mathrm{F}}$ pollution indices indicate non-contamination on soils around both the industry and the control site as describe in Table 1.

\begin{tabular}{|c|c|c|c|c|c|c|c|}
\hline & Parameter & $\mathrm{Fe}$ & $\mathrm{Ni}$ & Co & $\mathrm{Pb}$ & $\mathrm{Cd}$ & $\mathrm{Cr}$ \\
\hline \multirow{6}{*}{$\begin{array}{l}\text { Test } \\
\text { Soil }\end{array}$} & Mean (mg/kg) & $4625.32 \pm 0.252$ & $48.20 \pm 0.128$ & $36.85 \pm 0.046$ & $321.45 \pm 0.038$ & ND & ND \\
\hline & average shale $(\mathrm{mg} / \mathrm{kg})$ & 41000 & 80 & 20 & 14 & 0.11 & 90 \\
\hline & $I_{\text {geo }}$ value & $<0$ & $<0$ & 0.30 & 3.9 & $<0$ & $<0$ \\
\hline & $I_{\text {geo }}$ class & Uncont. & Uncont. & Uncont. & Moderately cont. & Uncont. & Uncont. \\
\hline & $\mathrm{CF}$ & 0.113 & 0.603 & 1.842 & 22.96 & $<0$ & $<0$ \\
\hline & CF remark & Uncont. & Uncont. & Cont. & Cont. & Uncont. & Uncont. \\
\hline \multirow{6}{*}{$\begin{array}{l}\text { Control } \\
\text { Soil }\end{array}$} & Mean (mg/kg) & $3675.44 \pm 1.14$ & $27.49 \pm 0.22$ & $37.05 \pm 0.044$ & $174.23 \pm 0.088$ & ND & ND \\
\hline & average shale $(\mathrm{mg} / \mathrm{kg})$ & 41000 & 80 & 20 & 14 & 0.11 & 90 \\
\hline & $I_{\text {geo }}$ value & 0 & 0 & 0.31 & 3.1 & $<0$ & $<0$ \\
\hline & $I_{\text {geo }}$ class & Uncont. & Uncont. & Uncont. & Strongly cont. & Uncont. & Uncont. \\
\hline & $\mathrm{C}_{\mathrm{F}}$ & 0.089 & 0.343 & 1.852 & 12.445 & $<0$ & $<0$ \\
\hline & $C_{F}$ remark & Uncont. & Uncont. & Cont. & Cont. & Uncont. & Uncont. \\
\hline
\end{tabular}

Table 3: Mean concentration $(\mathrm{mg} / \mathrm{kg})$ average shale $(\mathrm{mg} / \mathrm{kg})$, geo-accumulation index (Igeo) values and enrichment factor of heavy metals in soils. 


\section{Determination of nickel concentration}

The mean concentrations of $\mathrm{Ni}$ in the test and control soil were $48.20 \pm 0.128$ and $27.50 \pm 0.11 \mathrm{mg} / \mathrm{kg}$ respectively as presented in Table 3 , there is a significant difference between the nickel content of the test and control soil at $95 \%$ confidence limit where the content in the test soil is about double the content in the control soil. Nevertheless, these concentrations are generally lower than the $80 \mathrm{mg} / \mathrm{kg}$ concentration of $\mathrm{Ni}$ in the background as reported by Barbalace [16] and as well as the $75 \mathrm{mg} / \mathrm{kg}$ maximum limit set by the European Union [20,21]. Likewise, the Igeo and CF pollution indices indicate uncontamination with respect to $\mathrm{Ni}$ on soils around both the industry and the control site as describe in Table 1.

\section{Determination of cobalt concentration}

The mean concentrations of cobalt in the test and control soil were $36.85 \pm 0.046$ and $37.05 \pm 0.044 \mathrm{mg} / \mathrm{kg}$ respectively as presented in Table 3 and Figure 1, These concentrations are generally higher than the $20 \mathrm{mg} / \mathrm{kg}$ concentration of Co in the background as reported by Barbalace [16] but are generally below the $50 \mathrm{mg} / \mathrm{kg}$ maximum limit of Australian standard for soils [21]. Likewise, the $\mathrm{I}_{\text {geo }}$ and CF pollution indices of $(0.30$ and 0.31$)$ and (1.842 and 1.852) respectively indicates un-contamination as describe in Table 1.

\section{Determination of lead concentration}

The mean concentrations of lead in the test and control soil were $321.45 \pm 0.038$ and $174.23 \pm 0.088 \mathrm{mg} / \mathrm{kg}$ respectively as presented in Table 3 and Figure 1, there is a significant difference between the lead content of the test and control soil at $95 \%$ confidence limit. Also, these concentrations are generally much higher than the $14 \mathrm{mg} / \mathrm{kg}$ concentration of $\mathrm{Pb}$ in the background as reported by Barbalace [16] and are also above the $100 \mathrm{mg} / \mathrm{kg}$ maximum limit of Australian standard [21]; as well as the $210 \mathrm{mg} / \mathrm{kg}$ intervention values set by the Department of Petroleum Resources except the control soil which is below the intervention level [22,23]. Likewise, the $\mathrm{I}_{\text {geo }}$ and $\mathrm{CF}$ pollution indices of (3.9 and 3.1) and (22.96 and 12.445) respectively indicating strong contamination. High lead in the soil can be transfer into biota resulting in health challenge associated with brain damage in children and other symptoms may include abdominal pain, constipation, headaches, irritability, memory problems, inability to have children, and tingling in the hands and feet [24].

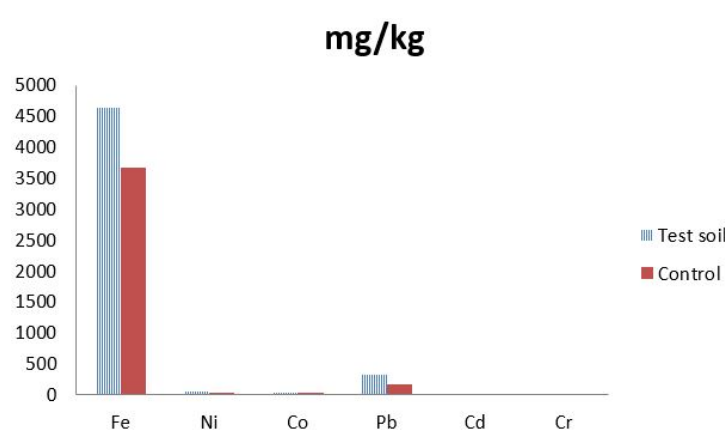

Figure 1: Mean concentration of heavy metals in soil around the packaging industry.

\section{Statistical analysis}

Comparing mean using IBM SPSS Statistics 20 reveals that there is significance difference in organic carbon, organic matter, nitrogen, available phosphorus and the cation exchange capacity except $\mathrm{pH}$, likewise the mean concentration of metals in soils around the packaging company significantly different with that in the control soil $(\mathrm{P}<0.05)$ suggesting that anthropogenic activity may have brought about the variation. Correlation analysis of the physiochemical properties and metal content of the test soil reveals a strong positive relationship between cation exchange capacity versus organic carbon and organic matter content $(\mathrm{P} \leq 0.01)$ implying that their presence in the soil enhances the capacity of the soil to hold and retain cations. A significant correlation was equally obtaining among nickel, available phosphorus and nitrogen $(\mathrm{P} \leq 0.01)$ suggesting that they might have emanate from the same source.

\section{Conclusion}

The results obtained from the analysis of soils around packaging company, Akwanga in order to assess the impact of the industry on the metal levels of surrounding soil reveals that the dominant metal concentrations were in the order: $\mathrm{Fe}>\mathrm{Pb}>\mathrm{Ni}>\mathrm{Co}$ while $\mathrm{Cd}$ and $\mathrm{Cr}$ were below detection limit. The Geo-accumulation index and contamination factor indicates high contamination of the soil with lead which a non-essential element responsible for lead poisoning. Also, the statistical analysis reveals a significant difference between the mean content of heavy metal between the soil around the industry and the soil around the control site cobalt suggest metal enrichment is due to anthropogenic activity since the metal level in the test soil were generally higher with exception of cobalt.

\section{Competing Interests}

Authors have declared that no competing interests exist.

\section{References}

1. Foramfera (2018) Foraminifera Market Research Reports.

2. Erdogan M (2009) Monitoring and Statistical Assessment of Heavy Metal Pollution in Sediments along Izmir Bay Using ICP-MS. A Thesis, Graduate School of Engineering and Sciences of Yzmir Institute of Technology, Turkey, pp: 1-100.

3. Denton GRW, Bearden BG, Concepcion LP, Siegrist HG, Vann DT, et al. (2001) Contaminant Assessment of Surface Sediments from Tanapag Lagoon, Saipan. Water and Environmental Research Institute of the Western Pacific, University of Guam, Mangilao, Guam, USA.

4. Sepehri A, Sarrafzadeh MH (2018) Effect of nitrifiers community on fouling mitigation and nitrification efficiency in a membrane bioreactor. Chemical Engineering and Processing-Process Intensification 128: 10-18.

5. Xie XJ, Cheng HX (2001) Global Geochemical Mapping and its Implementation in the Asia-Pacific Region. Appl Geochem 16: 1309-1321.

6. Motsara MR, Roy RN (2008) Guide to laboratory establishment for plant nutrient analysis. Fertilizer and Plant Nutrition Bulletin 19: 17-22.

7. Walkley A, Black IA (1934) An Examination of the Degtjareff Method for Determining Organic Carbon in Soils: Effect of Variations in Digestion Conditions and Inorganic Soil Constituents. Soil Science 63: 251-263.

8. Souza DM, Morais PAO, Matsushige I, Rosa LA (2016) Development of Alternative Methods for Determining Soil Organic Matter. Rev Bras Cienc Solo 40: 1-17.

9. Bray RH, Kurtz LT (1945) Determination of total, organic and available forms of phosphorus in soils. Soil Sci 59: 30-45. 
Citation: Yerima EA, Donatus RB, Opara IJ, Egah GO and Ani JD (2018) Assessment of Heavy Metals Level of Soils Around Sacks and Packaging Company, Akwanga Nasarawa State, Nigeria. J Environ Anal Chem 5: 251. doi:10.4172/2380-2391.1000251

Page 5 of 5

10. Motsara MR, Roy RN (2008) Guide to laboratory establishment for plant nutrient analysis. Fertilizer and Plant Nutrition Bulletin 19: 17-22.

11. Brown JR, Warncke DD (1988) Recommended cation tests and measures of cation exchange capacity. Agric Exp Sta, pp: 15-16.

12. Ross D (2009) Soil Cation Exchange Capacity in Recommended Soil Testing Procedures for the North Eastern United States.

13. Muller G (1969) Index of Geoaccumulation in sediments of the Rhine River. Geo J 2: 108-118.

14. Itodo AU, Ubi-mago M, Wuana RA (2018) Environmental Impact of Abandoned Asphalt Production Site on Soil, Water and Vegetables from Near Farmlands. Journal of Geoscience and Environment Protection 6: 107-122.

15. Shaari H, Bidai J, Hidayu SN, Azmi M, Sultan YM (2015) Spatial Distribution of Selected Heavy Metals in Surface Sediments of the EEZ of the East Coast of Peninsular Malaysia. International Journal of Oceanography 1: 1155-1166.

16. Barbalace K (2007) Periodic Table of Elements.

17. Zhang J, Liu CL (2002) Riverine composition and estuarine geochemistry of particulate metals in China-Weathering features anthropogenic impact and chemical fluxes. Estuarine Coastal and Shelf Science 54: 1051-1070.

18. Rahman SH, Khanam D, Adyel TM, Islam MS, Ahsan MA, et al. (2012) Assessment of Heavy Metal Contamination of Agricultural Soil around
Dhaka Export Processing Zone (DEPZ), Bangladesh: Implication of Seasonal Variation and Indices. Applied Sci 2: 584-601.

19. Ramos FT, Dores EFC, Weber OLDS, Beber DC, Campelo JHJ, et al. (2018) Soil organic matter doubles the cation exchange capacity of tropical soil under no-till farming in Brazil. J Sci Food Agric 98: 3595-3602.

20. McGrath S, Chang A, Page A, Witter E (1994) Land application of sewage sludge: scientific perspectives of heavy metal loading limits in Europe and the United States. Environ Rev 2: 108-118.

21. Maleki A, Hassan A, Nazmara S, Zandi S, Mahvi AH (2014) Spatial distribution of heavy metal in soil, water and vegetation of farms in Sanandaj, Kurdistan, Iran. Journal of Environmental Health Science and Engineering 12: 136-142.

22. EGASPIN (2002) Environmental Guidelines and Standards for the Petroleum Industry in Nigeria (EGASPIN). Department of Petroleum Resources, Lagos, Nigeria.

23. Agbaji EB, Abechi SE, Emmanuel SA (2015) Assessment of Heavy Metals Level of Soil in Kakuri Industrial Area of Kaduna, Nigeria. Journal of Scientific Research and Reports 4: 68-78.

24. Castellino N, Sannolo N, Castellino P (1994) Inorganic Lead Exposure and Intoxications, CRC Press, p: 86. 